\title{
EFFICIENT BAEYER-VILLIGER ELECTRO-OXIDATION OF KETONES WITH MOLECULAR OXYGEN USING AN ACTIVATED CARBON FIBER ELECTRODE IN IONIC LIQUID [bmim][OTf]
}

\author{
Yu Lin $\mathrm{Hu}^{1,2, *}$, Yi Bi Xie ${ }^{2}$, and De Jiang $\mathrm{Li}^{2}$ \\ ${ }^{1}$ College of Chemistry and Environmental Engineering, Yancheng Teachers University, \\ Yancheng 224002, P. R. China \\ ${ }^{2}$ College of Materials and Chemical Engineering, China Three Gorges University, Yichang \\ 443002, People's Republic of China
}

(Received April 5, 2015; revised July 3, 2016)

\begin{abstract}
A new and efficient method for the synthesis of lactones and esters involving the application of an molecular oxygen-based electro-catalytic oxidation system and ionic liquid [bmim][OTf] as electrolyte has been developed. The reaction between various ketones with molecular oxygen proceeds in a three-electrode cell under constant current conditions in [bmim][OTf] at room temperature to give the corresponding esters and lactones in good to excellent isolated yield. Additionally, the possible mechanism of Baeyer-Villiger oxidation of ketones in the electro-catalytic system is proposed.
\end{abstract}

KEY WORDS: Baeyer-Villiger oxidation, Ketone, Molecular oxygen, Electrocatalysis, Ionic liquid

\section{INTRODUCTION}

Lactones and esters are important classes of chemicals that have been used extensively as synthetic intermediates in the preparation of a variety of fine or special chemicals such as drugs, steroids, pheromones, etc $[1,2]$. Up to now, many publications in the open literature have been found in synthesis of these types of compounds, and a well known method for such a synthesis constitutes the Baeyer-Villiger oxidation of ketones [3, 4]. Traditional methods for performing such a transformation generally involve the use of stoichiometric amount of the strongest oxidizing reagents (e.g., trifluoroperacetic acid, peroxyacetic acid, and perbenzoic acid) [5-8], and suffer from considerable drawbacks such as low yield, harsh or delicate reaction condition, and a large amount of waste by-products. Various reagents employed as the oxygen donors have been developed for this conversion include sodium perborate [9], potassium peroxydisulfate $\left(\mathrm{K}_{2} \mathrm{~S}_{2} \mathrm{O}_{8}\right)[10,11]$, sodium perborate $\left(\mathrm{NaBO}_{3}\right)[11], m$-CPBA $[12,13]$, NADPH $[14,15]$, phenylacetone monooxygenase (PAMO) [16], $\mathrm{H}_{2} \mathrm{O}_{2}$ [17-22], oxone [23], h- $\mathrm{SiO}_{2} \cdot \mathrm{KHSO}_{5}$ [24], and other complexes [25-30]. However, some of these procedures are invariably associated with one or more disadvantages such as the use of expensive reagents, long reaction time, difficulties in work up, environmental hazards, and difficulties in recycling of the catalyst. Molecular oxygen is a safe, economical and environmentally-benign reagent, molecular oxygen has recently been utilized as an attractive oxidant due to cheap price and environmental friendly nature. Therefore, molecular oxygen-based protocols are powerful methods for the oxidation of ketones and attract a great attention, which make the reactions of choice in large and industrial scale applications. A number of catalytic oxidation processes based on the combination of transition metals or organocatalysts and $\mathrm{O}_{2}$ have been developed for such a conversion [31-34]. However, these methods still suffered from environmental hazards, poor recovery of expensive metal catalysts and laborious workup procedures. Consequently, search for new and environmentally benign synthetic methodologies for BaeyerVilliger oxidation of ketones that address these drawbacks remains to be of value and interest.

*Corresponding author. E-mail: huyulin1982@163.com 
Ionic liquids (ILs) have attracted considerable attention during the past few years due, in some cases, to their favourable properties such as very low vapor pressure, wide liquid temperature range, good ionic conductivity, excellent electrochemical properties, extraction and catalytic ability [35-38]. Therefore, ILs have recently gained recognition of scholars from various fields such as separation science [39], chemical synthesis [40], electrochemistry [41], and catalysis $[42,43]$. The good chemical stability, high electronic conductivity and wide electrochemical windows made ILs more suitable for electrochemical research [44-46]. Electrons are green reactants and can be used in oxidation and reduction reactions. Also, electrodes can act as catalysts and are easily separated from the reaction mixture [47]. Between different electrochemical reactions, the electrochemical oxidation method is a powerful strategy, and different types of electrochemical oxidation have been reported [48-50]. Herein, we would like to report a green and efficient protocol for the anodic electro-mediated aerobic oxidation of ketones to lactones and esters via constant current electro-catalysis in a three-electrode cell, in the presence of ionic liquid [bmim][OTf] at room temperature (Scheme 1), aiming to supply a new way for the synthesis of lactones and esters from ketones.

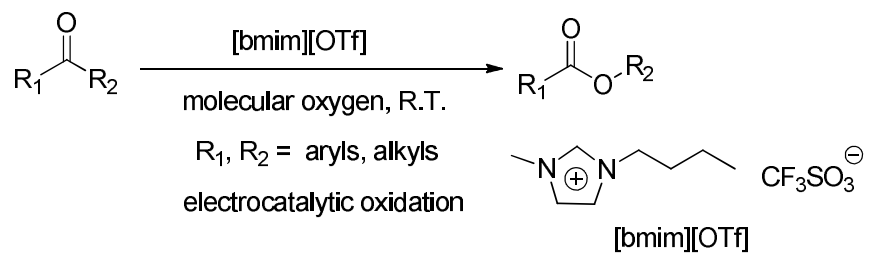

Scheme 1. Baeyer-Villiger electro-oxidation of ketones.

\section{EXPERIMENTAL}

Apparatus and reagents

All the chemicals were from commercial sources without any pretreatment. All reagents were of analytical grade. The ionic liquids were synthesized according to the literature procedure [38]. ${ }^{1} \mathrm{H}$ NMR spectra and ${ }^{13} \mathrm{C}$ NMR spectra were recorded on a Bruker $500-\mathrm{MHz}$ spectrometer using $\mathrm{CDCl}_{3}$ as the solvent with tetramethylsilane (TMS) as an internal standard. GC analyses were performed on a Shimadzu-14B gas chromatography equipped with HP-1 capillary column (30 $\mathrm{m}, 0.25 \mathrm{~mm}, 0.25 \mathrm{~mm}$ ). Melting points were recorded on a Buchi R-535 apparatus and are uncorrected. Elemental analysis was performed on a Vario EL III instrument (Elmentar Anlalysensy Teme GmbH, Germany). Constant-current coulometry was performed using a potentiostat/galvanostat model 283 (PAR EG\&G, USA). The working electrode used in the oxidation experiments was an activated carbon fiber and platinum wire was used as the counter electrode and a platinum wire as a reference electrode with a diameter of $0.5 \mathrm{~mm}$.

General procedure for oxidation reactions

A mixture of [bmim] [OTf] $(20 \mathrm{~mL})$ and ketone $(0.1 \mathrm{~mol})$ in a three-electrode cell fitted with activated carbon fiber as the anode and Pt cathode was subjected to electro-catalytic oxidation at a constant current at room temperature for an appropriate time. $\mathrm{O}_{2}$ gas was charged into the cell through a $\mathrm{O}_{2}$ bomb to a desired amount at the flow rate of $15 \mathrm{~mL} \mathrm{~min}^{-1}$. A magnetic stirrer was employed during the electro-oxidation. The progress of the reaction was monitored by GC. After completion of the reaction, the organic phase was extracted with dichloromethane $(3 \times 20$ $\mathrm{mL}$ ). The solvent was removed and the residue was purified by preparative thin-layer 
chromatography on silica gel (ethyl acetate: hexane, 1:10) to afford the desired pure product. The rest of the ionic liquid was recovered. Fresh substrates were then recharged to the recovered electro-catalytic system and then recycled under identical reaction conditions. The target substrates were characterized by Elemental analysis, NMR spectra or compared with their authentic samples. Spectroscopic data for selected products is as follows.

Methyl benzoate (Table 3, entry 1). Colourless oil, bp: 196-199 ${ }^{\circ} \mathrm{C} / 760 \mathrm{~mm}$ (Ref. [54] 198-199 $\left.{ }^{\circ} \mathrm{C} / 760 \mathrm{~mm}\right)$.

Methyl 4-methylbenzoate (Table 3, entry 2). Colourless oil, bp: $221-223{ }^{\circ} \mathrm{C} / 15 \mathrm{~mm}$ (Ref. [12] $222-223{ }^{\circ} \mathrm{C} / 760 \mathrm{~mm}$ ).

Methyl 2-methylbenzoate (Table 3, entry 3). Colourless oil, bp: $205-208^{\circ} \mathrm{C} / 760 \mathrm{~mm}$ (Ref. [54] $\left.207-208^{\circ} \mathrm{C} / 760 \mathrm{~mm}\right)$.

Methyl 4-methoxybenzoate (Table 3, entry 4). White solid, mp: 46-48 ${ }^{\circ} \mathrm{C}$ (Ref. [10] 47-49 ${ }^{\circ} \mathrm{C}$ ). ${ }^{1} \mathrm{H}$ NMR: $\delta 3.78\left(\mathrm{~s}, \mathrm{CH}_{3}, 3 \mathrm{H}\right), 3.86\left(\mathrm{~s}, \mathrm{CH}_{3}, 3 \mathrm{H}\right), 6.82-6.87(\mathrm{~m}, \mathrm{Ar}-\mathrm{H}, 2 \mathrm{H}), 7.07-7.15(\mathrm{~m}, \mathrm{Ar}-\mathrm{H}$, $2 \mathrm{H}) .{ }^{13} \mathrm{C}$ NMR: $\delta$ 50.7, 55.4, 113.8, 123.1, 131.2, 163.5, 167.8. Anal. calcd. for $\mathrm{C}_{9} \mathrm{H}_{10} \mathrm{O}_{3}: \mathrm{C}$, 65.02; H, 6.04; O, 28.86. Found: C, 65.05; H, 6.07; O, 28.88.

Methyl 4-ethylbenzoate (Table 3, entry 5). Colourless oil, bp: $106-109{ }^{\circ} \mathrm{C} / 15 \mathrm{~mm}$ (Ref. [54] $\left.105-107^{\circ} \mathrm{C} / 15 \mathrm{~mm}\right)$

Methyl 4-(tert-butyl)benzoate (Table 3, entry 6). Colourless oil, bp: $134-136{ }^{\circ} \mathrm{C} / 15 \mathrm{~mm}$ (Ref. [12] $\left.135-137{ }^{\circ} \mathrm{C} / 15 \mathrm{~mm}\right) .{ }^{1} \mathrm{H}$ NMR: $\delta 1.31\left(\mathrm{~s}, \mathrm{CH}_{3}, 9 \mathrm{H}\right), 3.87\left(\mathrm{~s}, \mathrm{CH}_{3}, 3 \mathrm{H}\right), 7.21-7.32(\mathrm{~m}, \mathrm{Ar}-\mathrm{H}$, $2 \mathrm{H}), 7.78-7.86$ (m, Ar-H, 2H). ${ }^{13} \mathrm{C}$ NMR: $\delta$ 30.8, 34.5, 51.1, 122.7, 126.4, 130.3, 157.8, 168.2. Anal. calcd. for $\mathrm{C}_{12} \mathrm{H}_{16} \mathrm{O}_{2}$ : C, 74.95; H, 8.36; O, 16.62. Found: C, 74.97; H, 8.39; O, 16.64 .

Methyl 4-(trifluoromethyl)benzoate (Table 3, entry 7). Colourless oil, bp: $85-87^{\circ} \mathrm{C} / 15 \mathrm{~mm}$ (Ref. [54] $\left.86-87^{\circ} \mathrm{C} / 15 \mathrm{~mm}\right)$.

Methyl 4-nitrobenzoate (Table 3, entry 8). Light yellow solid, mp: 96-98 ${ }^{\circ} \mathrm{C}$ (Ref. [54] 9597 $\left.{ }^{\circ} \mathrm{C}\right) .{ }^{1} \mathrm{H}$ NMR: $\delta 3.91\left(\mathrm{~s}, \mathrm{CH}_{3}, 3 \mathrm{H}\right), 8.27-8.38(\mathrm{~m}, \mathrm{Ar}-\mathrm{H}, 4 \mathrm{H}) .{ }^{13} \mathrm{C}$ NMR: $\delta$ 51.7, 124.2, 130.9, 135.9, 158.7, 169.3. Anal. calcd. for $\mathrm{C}_{8} \mathrm{H}_{7} \mathrm{NO}_{4}$ : C, 53.01; H, 3.84; N, 7.72; O, 35.31. Found: C, 53.04; H, 3.89; N, 7.73; O, 35.33 .

Dimethyl terephthalate (Table 3, entry 9). White solid, mp: 140-142 ${ }^{\circ} \mathrm{C}$ (Ref. [54] 141-142 ${ }^{\circ} \mathrm{C}$ ).

Methyl 4-bromobenzoate (Table 3, entry 10). Light yellow solid, mp: 79-82 ${ }^{\circ} \mathrm{C}$ (Ref. [54] 78-81 $\left.{ }^{\circ} \mathrm{C}\right)$.

propyl 4-methylbenzoate (Table 3, entry 11). Colourless oil, bp: $112-114{ }^{\circ} \mathrm{C} / 15 \mathrm{~mm}$ (Ref. [54] $\left.112-113^{\circ} \mathrm{C} / 15 \mathrm{~mm}\right)$.

Pentyl 4-methylbenzoate (Table 3, entry 12). Colourless oil, bp: $284-287^{\circ} \mathrm{C} / 760 \mathrm{~mm}$ (Ref. [54] 285-286 $\left.{ }^{\circ} \mathrm{C} / 760 \mathrm{~mm}\right) .{ }^{1} \mathrm{H}$ NMR: $\delta 0.93\left(\mathrm{t}, J=7.6 \mathrm{~Hz}, \mathrm{CH}_{3}, 3 \mathrm{H}\right), 1.31-1.37\left(\mathrm{~m}, \mathrm{CH}_{2} \mathrm{CH}_{2}, 4 \mathrm{H}\right)$, $1.84\left(\mathrm{~m}, \mathrm{CH}_{2}, 2 \mathrm{H}\right), 2.37\left(\mathrm{~s}, \mathrm{CH}_{3}, 3 \mathrm{H}\right), 4.25\left(\mathrm{t}, J=7.6 \mathrm{~Hz}, \mathrm{CH}_{2}, 2 \mathrm{H}\right), 7.24-7.35(\mathrm{~m}, \mathrm{Ar}-\mathrm{H}, 2 \mathrm{H})$, 7.76-7.85 (m, Ar-H, 2H). ${ }^{13} \mathrm{C}$ NMR: $\delta$ 14.5, 20.9, 22.1, 27.5, 28.4, 62.7, 127.5, 128.2, 130.1, 147.6, 165.5. Anal. calcd. for $\mathrm{C}_{13} \mathrm{H}_{18} \mathrm{O}_{2}$ : C, 75.66; H, 8.77; O, 15.48. Found: C, 75.69; H, 8.80; $\mathrm{O}, 15.51$. 
Tetrahydro-2H-pyran-2-one (Table 3, entry 13). Colourless oil, bp: $229-232{ }^{\circ} \mathrm{C} / 760 \mathrm{~mm}$ (Ref. [54] $\left.230-231^{\circ} \mathrm{C} / 760 \mathrm{~mm}\right)$.

Oxepan-2-one (Table 3, entry 14). Colourless oil, bp: 233-235 ${ }^{\circ} \mathrm{C} / 760 \mathrm{~mm}$ (Ref. [54] 234-235 $\left.{ }^{\circ} \mathrm{C} / 760 \mathrm{~mm}\right)$.

6-Methyltetrahydro-2H-pyran-2-one (Table 3, entry 15). Colourless oil, bp: $111-113{ }^{\circ} \mathrm{C} / 15 \mathrm{~mm}$ (Ref. [54] 110-112 $\left.{ }^{\circ} \mathrm{C} / 15 \mathrm{~mm}\right) .{ }^{1} \mathrm{H}$ NMR: $\delta 1.39$ (d, $\left.J=8.0 \mathrm{~Hz}, \mathrm{CH}_{3}, 3 \mathrm{H}\right), 1.73-1.89$ (m, $\left.\mathrm{CH}_{2} \mathrm{CH}_{2}, 4 \mathrm{H}\right), 2.36\left(\mathrm{~m}, \mathrm{CH}_{2}, 2 \mathrm{H}\right), 4.32(\mathrm{~m}, \mathrm{CH}, 1 \mathrm{H}) .{ }^{13} \mathrm{C}$ NMR: $\delta$ 19.4, 21.5, 29.8, 71.1, 170.3. Anal. calcd. for $\mathrm{C}_{6} \mathrm{H}_{10} \mathrm{O}_{2}$ : C, 63.13; H, 8.79; O, 28.02. Found: $\mathrm{C}, 63.14 ; \mathrm{H}, 8.83 ; \mathrm{O}, 28.03$.

7-Methyloxepan-2-one (Table 3, entry 16). Colourless oil, bp: $226-229{ }^{\circ} \mathrm{C} / 760 \mathrm{~mm}$ (Ref. [54] 227-228 $\left.{ }^{\circ} \mathrm{C} / 760 \mathrm{~mm}\right) .{ }^{1} \mathrm{H}$ NMR: $\delta 1.38\left(\mathrm{~d}, J=7.8 \mathrm{~Hz}, \mathrm{CH}_{3}, 3 \mathrm{H}\right), 1.45-1.71\left(\mathrm{~m}, \mathrm{CH}_{2} \mathrm{CH}_{2} \mathrm{CH}_{2}\right.$, $6 \mathrm{H}), 2.32\left(\mathrm{~m}, \mathrm{CH}_{2}, 2 \mathrm{H}\right), 4.19(\mathrm{~m}, \mathrm{CH}, 1 \mathrm{H}) .{ }^{13} \mathrm{C} \mathrm{NMR}: \delta 19.8,23.6,29.1,34.7,38.2,71.3,173.5$. Anal. calcd. for $\mathrm{C}_{7} \mathrm{H}_{12} \mathrm{O}_{2}$ : C, 65.58; H, 9.41; O, 24.94. Found: C, 65.60; H, 9.44; O, 24.97.

Oxocan-2-one (Table 3, entry 17). Colourless oil, bp: $235-237^{\circ} \mathrm{C} / 760 \mathrm{~mm}$ (Ref. [54] 236-237 $\left.{ }^{\circ} \mathrm{C} / 760 \mathrm{~mm}\right)$.

2-Oxabicyclo[3.2.1]octan-3-one (Table 3, entry 18). Colourless oil. ${ }^{1} \mathrm{H}$ NMR: $\delta$ 1.57-2.23 (m, $7 \mathrm{H}), 2.38-2.71\left(\mathrm{~m}, \mathrm{CH}_{2}, 2 \mathrm{H}\right), 4.82(\mathrm{~m}, \mathrm{CH}, 1 \mathrm{H}) .{ }^{13} \mathrm{C} \mathrm{NMR}: \delta 29.5,31.9,32.8,35.3,40.7,79.8$, 172.6. Anal. calcd. for $\mathrm{C}_{7} \mathrm{H}_{10} \mathrm{O}_{2}$ : C, 66.62; H, 7.98; O, 25.34. Found: C, 66.65; H, 7.99; O, 25.37 .

Propyl acetate (Table 3, entry 19). Colourless oil, bp: 100-102 ${ }^{\circ} \mathrm{C} / 760 \mathrm{~mm}$ (Ref. [54] 101-102 $\left.{ }^{\circ} \mathrm{C} / 760 \mathrm{~mm}\right)$.

Isopropyl acetate (Table 3, entry 20). Colourless oil, bp: $88-90{ }^{\circ} \mathrm{C} / 760 \mathrm{~mm}$ (Ref. [54] 88-89 ${ }^{\circ} \mathrm{C} / 760 \mathrm{~mm}$ ).

\section{RESULTS AND DISCUSSION}

Preliminary studies were performed using acetophenone as the model substrate on an activated carbon fiber (ACF) electrode in the presence of ionic liquid [bmim] [OTf] electrolyte to examine the effects of various reaction parameters on the typical oxidation (Table 1). In the absence of ionic liquid no product was detected (Table 1, entry 1 ). When the reaction was performed in the presence of the [bmim] [OTf] electrolyte $(5 \mathrm{~mL})$, the product could be obtained in a higher yield $46 \%$ (Table 1, entry 2$)$ in a shorter time $(60 \mathrm{~min})$. The yield improved with increasing amount of [bmim][OTf] (Table 1, entries 2-5), and reached maximum with $20 \mathrm{~mL}$ of [bmim][OTf] (Table 1, entry 5). However, further addition the amount of [bmim][OTf] (Table 1, entry 6), under the same conditions, the yield was not enhanced significantly. These experiments revealed that ionic liquid [bmim][OTf] electrolyte are crucial for the oxidation. On investigating the effect of current amount on the reaction yield, constant currents of 20, 25,30,35, and $40 \mathrm{~mA}$ were utilized. The best results were obtained in $30 \mathrm{~mA}$ current (Table 1, entry 5).

The effects of different electrolytes, such as [hmim][OTf], [dema][OTf], [bmim][OTf], $[\mathrm{bmim}]\left[\mathrm{PF}_{6}\right]$, and $[\mathrm{bmim}]\left[\mathrm{BF}_{4}\right]$, were tested on an ACF electrode in the reaction (Table 2, entries 1-5), and it was observed that [bmim][OTf] demonstrated the best performance (Table 2, entry 3). The different catalytic effects of ILs may be attributed to their different abilities of stabilizing and dissolving $\mathrm{O}_{2}$, the catalyst and the substrate. Under reaction conditions, $\mathrm{O}_{2}$ may be more soluble in [bmim][OTf], leading to higher effective concentration of the oxidant, which increases the encounter probabilities between the substrate and reactive species, and so the higher rate and yield of the reaction were observed. Furthermore, the electro-catalytic system 
could be typically recovered and reused with no appreciable decrease in yields and reaction rates (Table 2, entries 6 and 7). Besides ACF, other types of electrode materials were also tested in this model reaction (Table 2, entries 8-10). The results showed that ACF demonstrated the best performance.

Table 1. Screening of the reaction condition for the aerobic electro-catalytic oxidation of acetophenone $\mathrm{e}^{\mathrm{a}}$.

\begin{tabular}{|c|c|c|c|c|}
\hline Entry & {$[\mathrm{bmim}][\mathrm{OTf}](\mathrm{mL})$} & $\mathrm{I}(\mathrm{mA})$ & Time $(\mathrm{min})$ & ${\text { Yield }(\%)^{\mathbf{b}}}^{\mathbf{b}}$ \\
\hline 1 & -- & 60 & 100 & 0 \\
\hline 2 & 5 & 40 & 60 & 46 \\
\hline 3 & 15 & 30 & 20 & 81 \\
\hline 4 & 18 & 30 & 20 & 88 \\
\hline 5 & 20 & 30 & 20 & 90 \\
\hline 6 & 22 & 30 & 20 & 80 \\
\hline 7 & 20 & 35 & 20 & 83 \\
\hline 8 & 20 & 40 & 20 & 88 \\
\hline 9 & 20 & 25 & 20 & 85 \\
\hline 10 & 20 & 20 & 20 & \\
\hline
\end{tabular}

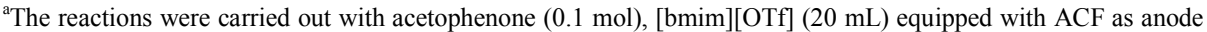
and Pt cathode with the bubbling of $\mathrm{O}_{2}$ gas $\left(15 \mathrm{~mL} \mathrm{~min}^{-1}\right)$ at room temperature. ${ }^{b}$ Isolated yield.

Table 2. Optimization of the conditions for the aerobic electro-catalytic oxidation of acetophenone ${ }^{\mathrm{a}}$.

\begin{tabular}{|c|c|c|c|c|}
\hline Entry & Electrolyte & Electrode material & Time (min) & Yield $(\%)^{b}$ \\
\hline 1 & [hmim][OTf] & $\mathrm{ACF}$ & 20 & 78 \\
\hline 2 & [dema][OTf] & ACF & 20 & 86 \\
\hline 3 & [bmim][OTf] & ACF & 20 & 90 \\
\hline 4 & {$[\mathrm{bmim}]\left[\mathrm{PF}_{6}\right]$} & $\mathrm{ACF}$ & 20 & 82 \\
\hline 5 & {$[\mathrm{bmim}]\left[\mathrm{BF}_{4}\right]$} & ACF & 20 & 80 \\
\hline 6 & [bmim][OTf] & $\mathrm{ACF}$ & 20 & $90^{\mathrm{c}}$ \\
\hline 7 & [bmim][OTf] & $\mathrm{ACF}$ & 20 & $89^{\mathrm{d}}$ \\
\hline 8 & [bmim][OTf] & Graphite rod & 20 & 78 \\
\hline 9 & [bmim][OTf] & Glass carbon & 30 & 84 \\
\hline 10 & [bmim][OTf] & $\mathrm{Ti} / \mathrm{TiO}_{2}$ & 20 & 81 \\
\hline
\end{tabular}

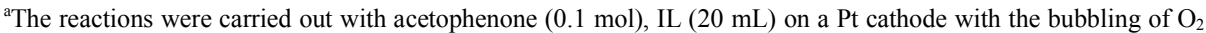
gas $\left(15 \mathrm{~mL} \mathrm{~min}{ }^{-1}\right)$ at constant current of $30 \mathrm{~mA} .{ }^{b}$ Isolated yield. ${ }^{\mathrm{c}}$ The first run. ${ }^{\mathrm{d}}$ The second run.

The electro-catalytic oxidation of a wide variety of ketones with molecular oxygen was successful and gave the desired products in good to excellent yields as summarized in Table 3. Various types of aryl, aliphatic, and naphthenic ketones can be successfully electro-oxidated to the corresponding esters and lactones with molecular oxygen (Table 3, entries 1-20), whereas the aryl ketones were less reactive, higher reaction constant current and longer reaction time were needed to reach good to excellent yields (Table 3, entries 1-12). Various functionalities such as alkyl, alkoxy, bromo, trifluoromethyl, acetyl and nitro groups can tolerate the reaction. It was also observed that the electronic nature of the substituents on the aromatic ring has some impact on the reaction rate and the yield. Aryl ketones, especially those with electron-donating substituents (Table 3, entries 2-6), were more reactive than those with electron-withdrawing substituents (Table 3, entries 7-10), provided excellent yields under milder reaction conditions. In addition, in order to examine a greater range of ketones to better illustrate the scope and limitations of the method, we investigated the reactions with long carbon chain ketones such as 1-( $p$-tolyl)butan-1-one, 1-( $p$-tolyl)hexan-1-one, and pentan-2-one (Table 2, entries 11, 12 and $19)$, excellent yields of the expected esters were obtained. 
Table 3. Aerobic electro-catalytic oxidation of ketones ${ }^{\mathrm{a}}$.

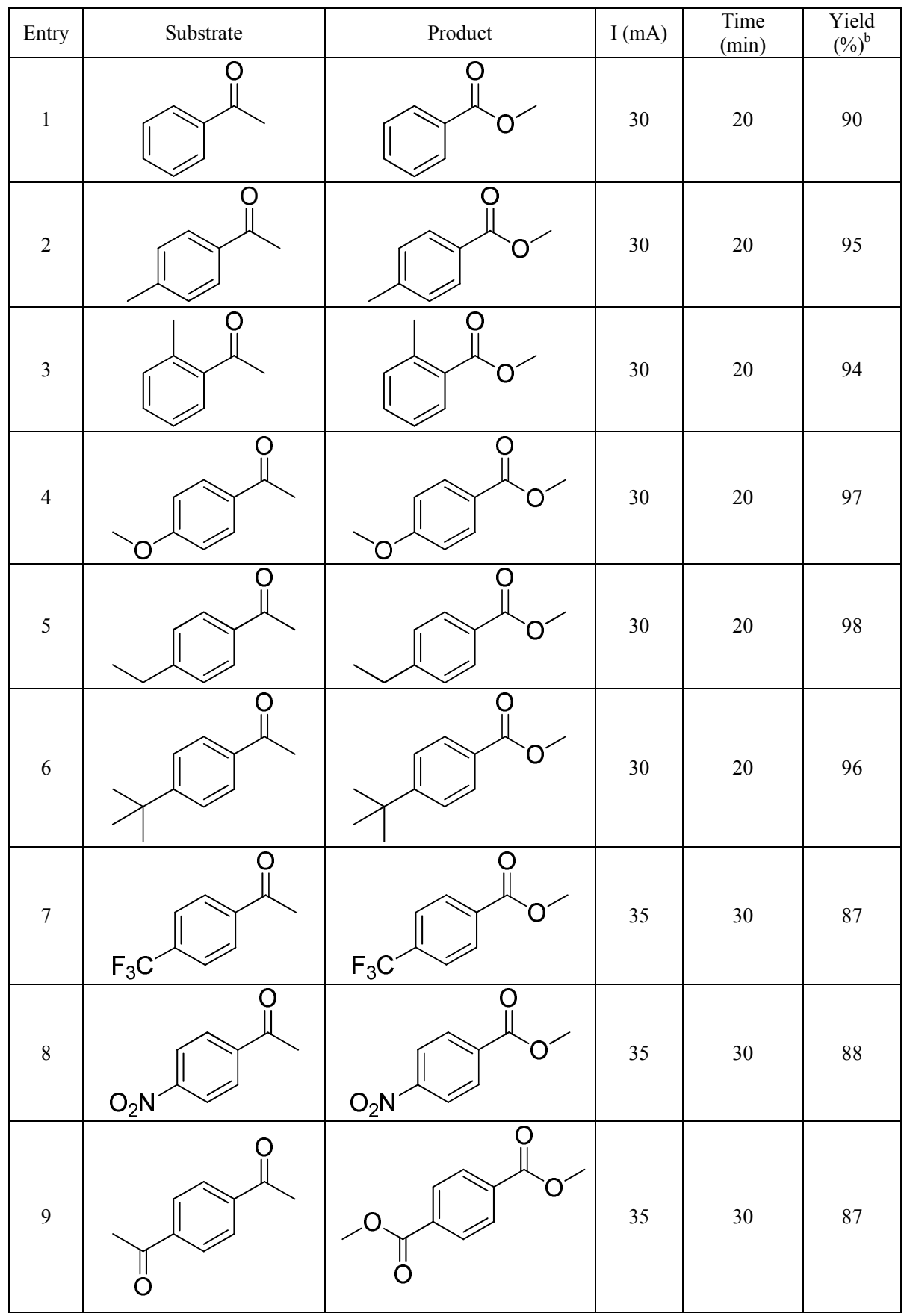

Bull. Chem. Soc. Ethiop. 2016, 30(2) 


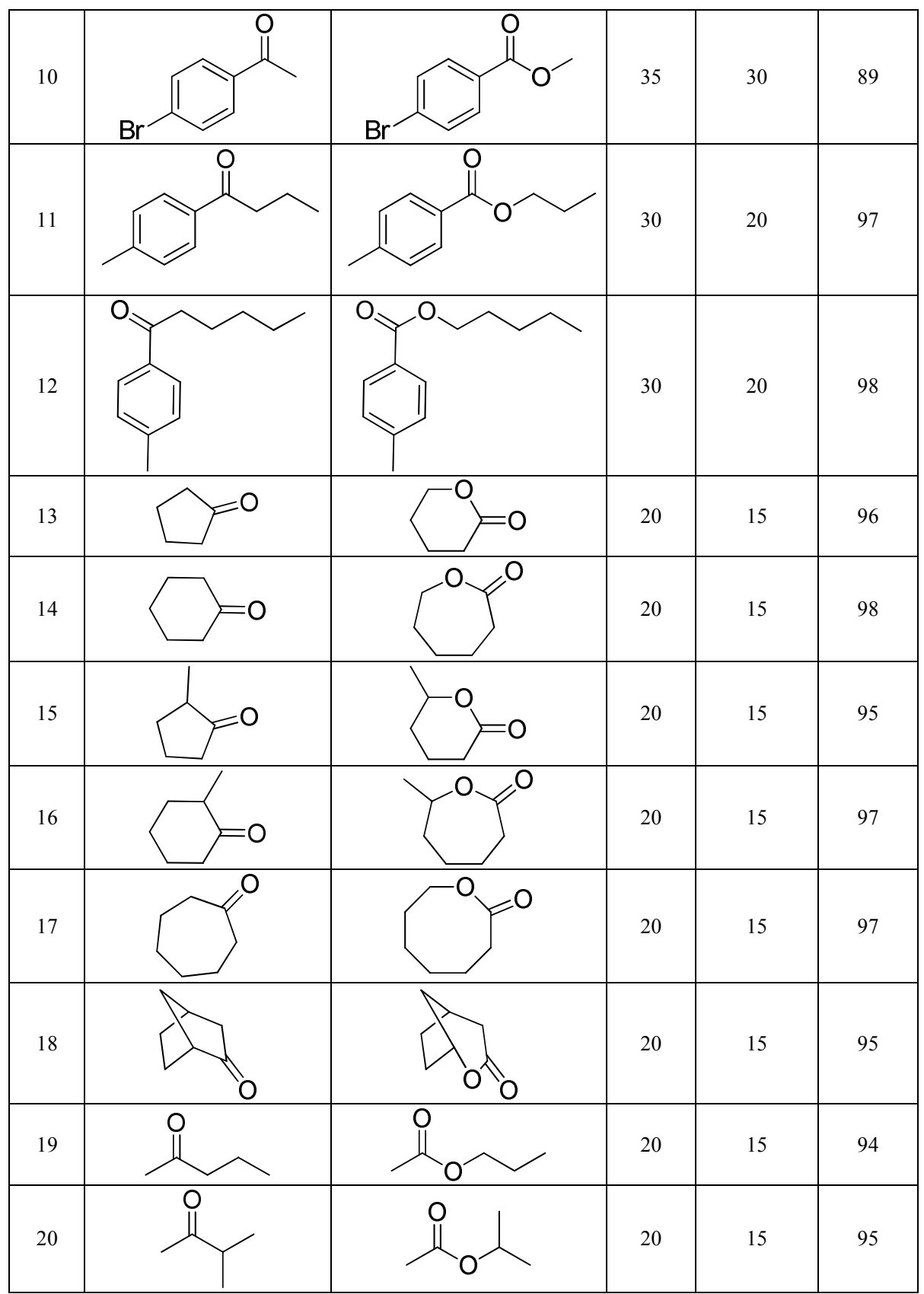

${ }^{\mathrm{a}}$ Unless otherwise noted, the reactions were carried out with ketone $(0.1 \mathrm{~mol})$, [bmim][OTf] $(20 \mathrm{~mL})$ equipped with ACF as anode and Pt cathode with the bubbling of $\mathrm{O}_{2}$ gas $\left(15 \mathrm{~mL} \mathrm{~min}^{-1}\right)$ at room temperature. ${ }^{b}$ Isolated yield. 
According to the literatures [51-53] and the observations in our reactions, taking the electrocatalytic oxidation of acetophenone with $\mathrm{O}_{2}$ as an example, a possible mechanism is proposed (Scheme 2). In the reaction, the electro-catalytic system equipped with ACF as anode and $\mathrm{Pt}$ cathode in [bmim][OTf] electrolyte can generate singlet oxygen (1) by visible constant current of $30 \mathrm{~mA}$ electro-catalysis of $\mathrm{O}_{2}$ (triplet state). Then, 1 reacts with the acetophenone to form acyl radical (2) and methylperoxyl radical (3), and the two radicals $\mathbf{2}$ and $\mathbf{3}$ are reacts with each other to form peroxy acid ester (4). 4 subsequently undergoes reaction with another acetophenone to form transition state (5), followed by Bayer-Villiger type rearrangement to generate two molecules of the desired product (6). It looks like that the formations of $\mathbf{2}$ and $\mathbf{5}$ are the rate-determining steps.

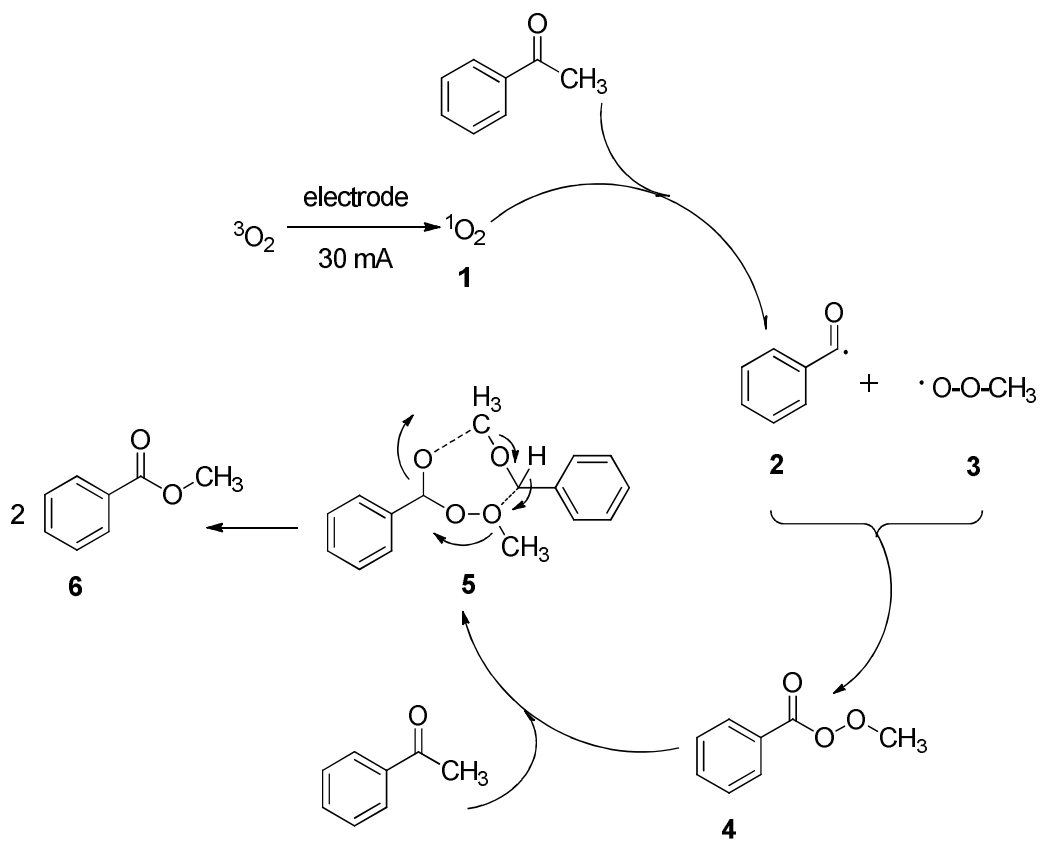

Scheme 2. Possible mechanism for the electro-oxidation of acetophenone.

\section{CONCLUSIONS}

In conclusion, a new and highly efficient electro-catalytic oxidation system equipped with ACF as anode and Pt cathode in [bmim][OTf] electrolyte has been developed, which is capable of converting ketones with molecular oxygen into the corresponding esters and lactones in good to excellent isolated yield. Mild reaction conditions, simplicity of operation, high yields, stability, easy isolation of products, and excellent recyclability of the catalytic system are the attractive features of this methodology. The scope, definition of the mechanism and synthetic application of this reaction are currently under study in our laboratory.

\section{ACKNOWLEDGEMENTS}

We thank the Natural Science Foundation of Jiangsu Province (no. BK20140460) for support of this research. 


\section{REFERENCES}

1. Larock, R.C. Comprehensive Organic Transformations, John Wiley: New York; 1999.

2. Lu, J.; Nie, K.; Xie, F.; Wang, F.; Tan, T. Process Biochem. 2007, 42, 1367.

3. ten Brink, G.J.; Arends, I.W.C.E.; Sheldon, R.A. Chem. Rev. 2004, 104, 4105.

4. Yamabe, S.; Yamazaki, S. J. Org. Chem. 2007, 72, 3031.

5. Smith, M.B.; March, J. Advanced Organic Chemistry: Reactions, Mechanisms, and Structure, John Wiley: New York; 2007.

6. Bach, R.D. J. Org. Chem. 2012, 77, 6801.

7. Chávez, G.; Rasmussen, J.A.; Janssen, M.; Mamo, G.; Hatti-Kaul, R.; Sheldon, R.A. Top. Catal. 2014, 57, 349.

8. Reyes, L.; Alvarez-Idaboy, J.R.; Mora-Diez, N. J. Phys. Org. Chem. 2009, 22, 643.

9. Espiritu, M.; Handley, P.N.; Neumann, R. Adv. Synth. Catal. 2003, 345, 325.

10. Zarrabi, S.; Mahmoodi, N.O.; Marvi, O. Monatsh. Chem. 2010, 141, 889.

11. Zarrabi, S.; Mahmoodi, N.O.; Tabatabaeian, K.; Zanjanchi, M.A. Chin. Chem. Lett. 2009, 20, 1400.

12. Yakura, T.; Kitano, T.; Ikeda, M.; Uenishi, J. Tetrahedron Lett. 2002, 43, 6925.

13. Romney, D.K.; Colvin, S.M.; Miller, S.J. J. Am. Chem. Soc. 2014, 136, 14019.

14. Jensen, C.N.; Cartwright, J.; Ward, J.; Hart, S.; Turkenburg, J.P.; Ali, S.T.; Allen, M.J.; Grogan, G. ChemBioChem 2012, 13, 872.

15. Brondani, P.B.; Dudek, H.M.; Martinoli, C.; Mattevi, A.; Fraaije, M.W. J. Am. Chem. Soc. 2014, 136, 16966.

16. van Beek, H.L.; de Gonzalo, G.; Fraaije, M.W. Chem. Commun. 2012, 3288.

17. Xu, S.; Wang, Z.; Zhang, X.; Ding, K. Angew. Chem. Int. Ed. 2008, 47, 2840.

18. Piscopo, C.G.; Loebbecke, S.; Maggi, R.; Sartori, G. Adv. Synth. Catal. 2010, 352, 1625.

19. Kirumakki, S.; Samarajeewa, S.; Harwell, R.; Mukherjee, A.; Herber, R.H.; Clearfield, A. Chem. Commun. 2008, 5556.

20. Ma, Q.; Xing, W.; Xu, J.; Peng, X. Catal. Commun. 2014, 53, 5.

21. Wang, Y.; Yokoi, T.; Otomo, R.; Kondo, J.N.; Tatsumi, T. Appl. Catal. A: Gen. 2015, 490, 93.

22. Uyanik, M.; Ishihara, K. ACS Catal. 2013, 3, 513.

23. Poladura, B.; Martínez-Castañeda, Á.; Rodríguez-Solla, H.; Llavona, R.; Concellón, C.; del Amo, V. Org. Lett. 2013, 15, 2810.

24. González-Núñez, M.E.; Mello, R.; Olmos, A.; Asensio, G. J. Org. Chem. 2006, 71, 6432.

25. Leisch, H.; Morley, K.; Lau, P.C.K. Chem. Rev. 2013, 113, 5700.

26. Flourat, A.L.; Peru, A.A.M.; Teixeira, A.R.S.; Brunissen, F.; Allais, F. Green Chem. 2015, 17,404

27. Beneventi, E.; Niero, M.; Motterle, R.; Fraaije, M.; Bergantino, E. J. Mol. Catal. B: Enzym. 2013, 98, 145.

28. Ochiai, M.; Yoshimura, A.; Miyamoto, K.; Hayashi, S.; Nakanishi, W. J. Am. Chem. Soc. 2010, 132, 9236.

29. Figg, T.M.; Cundari, T.R.; Gunnoe, T.B. Organometallics 2011, 30, 3779.

30. Drożdż, A.; Chrobok, A.; Baj, S.; Szymańska, K.; Mrowiec-Białoń, J.; Jarzębski, A.B. Appl. Catal. A: Gen. 2013, 467, 163.

31. Sinhamahapatra, A.; Sinha, A.; Pahari, S.K.; Sutradhar, N.; Bajaj, H.C.; Panda, A.B. Catal. Sci. Technol. 2012, 2, 2375.

32. Nabae, Y.; Rokubuichi, H.; Mikuni, M.; Kuang, Y.; Hayakawa, T.; Kakimoto, M. ACS Catal. 2013, 3, 230.

33. Kawabata, T.; Fujisaki, N.; Shishido, T.; Nomura, K.; Sano, T.; Takehira, K. J. Mol. Catal. A: Chem. 2006, 253, 279.

34. Chen, S.; Zhou, X.; Li, Y.; Luo, R.; Ji, H. Chem. Eng. J. 2014, 241, 138.

Bull. Chem. Soc. Ethiop. 2016, 30(2) 
35. Petkovic, M.; Seddon, K.R.; Rebelo, L.P.N.; Pereira, C.S. Chem. Soc. Rev. 2011, 40, 1383.

36. Zhang, X.C.; Liu, B. Bull. Chem. Soc. Ethiop. 2012, 26, 407; Keaveney, S.T.; Harper, J.B.; Croft, A.K. RSC $A d v$. 2015, 5, 35709; Hoogerstraete, T.V.; Binnemans, K. Green Chem. 2014, 16, 1594; Narayanaperuma, S.; da Silva, R.C.; Feu, K.S.; de la Torre, A.F.; Corrêa, A.G.; Paixã, M.W. Ultrason. Sonochem. 2013, 20, 793.

37. Heravi, M.M.; Ansari, P.; Ansari, P.; Saeedi, M.; Saeedi, M.; Tavakoli-Hosseini, N.; Karimi, N.; Karimi, N.; Tavakoli-Hosseini, N. Bull. Chem. Soc. Ethiop. 2011, 25, 315.

38. Zhang, S.J.; Lu, X.M. Ionic Liquids: From Fundamental Research to Industrial Applications, Science Press: Beijing; 2006.

39. Pino, V.; Germán-Hernández, M.; Martín-Pérez, A.; Anderson, J.L. Sep. Sci. Technol. 2012, 47, 264.

40. Xu, L.; Xia, J.; Wang, L.; Qian, J.; Li, H.; Wang, K.; Sun, K.; He, M. Chem. Eur. J. 2014, 20, 2244.

41. Yabuuchi, N.; Shimomura, K.; Shimbe, Y.; Ozeki, T.; Son, J.Y.; Oji, H.; Katayama, Y.; Miura, T.; Komaba, S. Adv. Energy Mater. 2011, 1, 759.

42. Hu, S.; Wang, A.; Li, X.; Wang, Y.; Löwe, H. Chem. Asian J. 2010, 5, 1171; Roy, S. R.; Chakraborti, A.K. Org. Lett. 2010, 12, 3866.

43. Hardacre, C.; Parvulescu, V. Catalysis in Ionic Liquids: From Catalyst Synthesis to Application, Royal Society of Chemistry: London; 2014.

44. Snyder, J.; Fujita, T.; Chen, M.W.; Erlebacher, J. Nature Mater. 2010, 9, 904.

45. Feroci, M.; Chiarotto, I.; D’Anna, F.; Forte, G.; Noto, R.; Inesi, A. Electrochim. Acta 2015, $153,122$.

46. Beneduci, A.; Cospito, S.; Deda, M.L.; Veltri, L.; Chidichimo, G. Nature Commun. 2014, 5, 3105.

47. Yoshida, J.I.; Kataoka, K.; Horcajada, R.; Nagaki, A. Chem. Rev. 2008, 108, 2265.

48. Berton, N.; Brachet, M.; Thissandier, F.; Bideau, J.L.; Gentile, P.; Bidan, G.; Brousse, T.; Sadki, S. Electrochem. Commun. 2014, 41, 31.

49. Rosen, B.R.; Werner, E.W.; O’Brien, A.G.; Baran, P.S. J. Am. Chem. Soc. 2014, 136, 5571.

50. Qi, Y.; Bian, T.; Choi, S. I.; Jiang, Y.; Jin, C.; Fu, M.; Zhang, H.; Yang, D. Chem. Commun. 2014, 560.

51. Kürti, L.; Czakó, B. Strategic Applications of Named Reactions in Organic Synthesis, Elsevier Academic Press: London; 2005.

52. Lehtinen, C.; Nevalainen, V.; Brunow, G. Tetrahedron 2000, 56, 9375.

53. Avelino, C.; Vicente, F.; Sara, I.; María, M.; Michael, R. J. Catal. 2004, $221,67$.

54. Porwoll, J. Aldrich Chemistry: Handbook of Fine Chemicals, Sigma-Aldrich Chemical Co.: Milwaukee; 2012-2014. 